\title{
Open access agreements for European and UK authors
}

Here follows a formal update on Brill's Open Access agreements. In 2021 Brill will publish in Open Access all research articles by authors affiliated to institutions in the Netherlands, United Kingdom, Sweden, and Austria. The participating institutions are listed below:

\begin{tabular}{|c|c|c|c|}
\hline The Netherlands & United Kingdom & Sweden & Austria \\
\hline $\begin{array}{l}\text { Erasmus University Rotterdam } \\
\text { Leiden University } \\
\text { Radbound University Nijmegen } \\
\text { Tilburg University } \\
\text { University of Amsterdam } \\
\text { University of Groningen } \\
\text { Utrecht University } \\
\text { VU University Amsterdam } \\
\text { Wageningen University }\end{array}$ & $\begin{array}{l}\text { Abertay University } \\
\text { Cardiff University } \\
\text { Edinburgh Napier University } \\
\text { Glasgow Caledonian University } \\
\text { Glasgow School of Art } \\
\text { Heriot-Watt University } \\
\text { King's College London } \\
\text { National Library of Scotland } \\
\text { National Museums Scotland } \\
\text { Queen Margaret University, Edinburgh } \\
\text { Royal Conservatoire of Scotland } \\
\text { School of Oriental and African Studies } \\
\text { The Robert Gordon University } \\
\text { The University of Manchester } \\
\text { University College London } \\
\text { University of Aberdeen } \\
\text { University of Bradford } \\
\text { University of Bristol } \\
\text { University of Cambridge } \\
\text { University of Dundee } \\
\text { University of Durham } \\
\text { University of Edinburgh } \\
\text { University of Exeter } \\
\text { University of Glasgow } \\
\text { University of Leeds } \\
\text { University of Liverpool } \\
\text { University of Nottingham } \\
\text { University of Oxford } \\
\text { University of Southampton } \\
\text { University of St Andrews } \\
\text { University of Stirling } \\
\text { University of Strathclyde } \\
\text { University of the Highlands and Islands } \\
\text { University of the West of Scotland } \\
\text { University of York }\end{array}$ & $\begin{array}{l}\text { Linnaeus University } \\
\text { Lund University } \\
\text { Mid-Sweden University } \\
\text { Södertörn University } \\
\text { Stockholm University } \\
\text { Swedish University of } \\
\text { Agricultural Sciences } \\
\text { Umeå University } \\
\text { University of Gothenburg } \\
\text { Uppsala University } \\
\text { Swedish Agency of Marine } \\
\text { and Water Management } \\
\text { Örebro Universitet } \\
\text { Högskolan Dalarna } \\
\text { Malmö Universitet }\end{array}$ & University of Vienna \\
\hline
\end{tabular}

These articles are sponsored by national consortia in a Transformative Agreement, which also gives universities access to Brill's full journal portfolio. 
Open Access articles are downloaded 25\% more often on average, are cited more often, and are cited more quickly upon publication. The author retains copyright and is encouraged to share the article widely across networks and databases relevant to their field. We expect that these agreements will therefore be highly advantageous for the visibility of articles and journals.

This may be valuable information to share with boards and potential authors. We have found that not all faculty members of participating institutions are aware of these arrangements. Please do not hesitate to get in touch, should you have questions.

Stefan Einarson

Acquisitions Editor

History of Science and Biology

BRILL 